\title{
PENERAPAN MODEL BERBASIS PROYEK DALAM MENINGKATKAN KETERAMPILAN MENULIS TEKS PROSEDUR SISWA KELAS VII H SMPN 21 KOTA MAKASSAR
}

\author{
Munirah, Akram Budiman Yusuf, Muh. Dahlan, Tasmiah \\ Prodi Pendidikan Bahasa dan Sastra Indonesia, Fakultas Keguruan dan Ilmu \\ Pendidikan Universitas Muhammadiyah Makassar, Jl. Sultan Alauddin No.259, Gn. \\ Sari, Kec. Rappocini, Kota Makassar, Sulawesi Selatan 90221, Kota Makassar, \\ Indonesia. \\ munirah@unismuh.ac.id
}

\begin{abstract}
ABSTRAK: Tujuan penelitian ini adalah untuk meningkatkan keterampilan menulis teks prosedur melalui penerapan model pembelajaran berbasisi proyek. Metode penelitian yang digunakan adalah kuantitatif dan deskripsi kualitatif. Pada studi awal, penelitian ini melibatkan mitra kerjasama guru Bahasa Indonesia SMPN 21 Kota Makassar untuk mendapatkan informasi terkait kondisi pembelajaran Bahasa Indonesia pada aspek keterampilan menulis teks prosedur dan tempat penelitian dalam menerapkan model pembelajaran berbasis Proyek. Jenis penelitian adalah penelitian tindakan kelas dengan Langkah perencanaan, pelaksanaan, observasi, dan refleksi. Subjek penelitian siswa kelas VII H SMPN 21 Kota Makassar. Teknik pengumpulan data dilakukan melalui tes, observasi dan wawancara. Teknik analisis data deskripsi kualitatif dan kuantitatif. Hasil penelitian menunjukkan bahwa keterampilan menulis teks prosedur meningkat dengan menerapkan model pembelajaran berbasis proyek. Hasil penelitian data siklus I siswa kelas VII H SMPN 21 kota Makassar dengan pemberian uji test membuat teks prosedur dan pemberian skor. Dengan total skor keseluruhan siswa 4.051 dengan dua kali uji test. Uji test pertama dengan nilai rata-rata 65,67 sedangkan nilai rata-rata uji test kedua 69,65 keseluruhan dari uji test pertama dan kedua yakni 67,51 dalam kategori cukup, sehingga dilakukan tahapan selanjutnya. Pada data siklus II siswa SMPN 21 kota Makassar dengan pemberian uji test membuat teks prosedur dan pemberian skor. Dengan total skor keseluruhan siswa 4.841 dengan dua kali uji test. Uji test pertama dengan nilai rata-rata 78,28, nilai rata-rata uji test kedua 83,58. Total rata-rata keseluruhan, yakni 80,63 dalam kategori baik.

KATA KUNCI: Kemampuan Menulis; Model Berbasis Proyek; Teks Prosedur;
\end{abstract}

\section{APPLICATION OF THE PROJECT-BASED MODEL IN IMPROVING PROCEDURE TEXT WRITING SKILLS FOR CLASS VII H SMPN 21 MAKASSAR CITY}

\begin{abstract}
The purpose of this study was to improve the procedural text writing skills through the application of a project-based learning model. The research method used is quantitative and qualitative description. In the initial study, this research involved partners with Indonesian language teachers at SMPN 21 Makassar City to obtain information related to the conditions of Indonesian language learning in the aspects of procedural text writing skills and research sites in applying the Project-based learning model. The type of research is classroom action research with planning, implementation, observation, and reflection steps. The research subjects were students of class VII H SMPN 21 Makassar City. Data collection techniques were carried out through tests, observations and interviews. Data analysis techniques are qualitative and quantitative descriptions. The results showed that the procedural text writing skills were improved by applying the project-based learning model. The results of the research on data from the first cycle of class VII H SMPN 21 Makassar city by giving a test test to make a procedure text and give a score. With a total score of 4,051 students with two tests. The first test with an average value of 65.67 while the average value of the second test was 69.65 overall from the first and second tests, namely 67.51 in the sufficient category, so the next stage was carried out. In the second cycle of data, the students of SMPN 21 Makassar city by giving a test test made a procedure text and gave a score. With a total score of 4,841 students with two tests. The first test with an average value of 78.28, the second test average value of 83.58. The overall average total, which is 80.63 in the good category.
\end{abstract}

KEYWORDS: Project Based Model; Procedure Text; Writing Skills 
Program Studi Pendidikan Bahasa dan Sastra Indonesia

FKIP Universitas Kuningan

$\begin{array}{llll}\text { Diterima: } & \text { Direvisi: } & \text { Distujui: } & \text { Dipublikasi: } \\ \text { 2021-09-18 } & - & 2021-09-28 & 2021-10-28\end{array}$

Pustaka : munirah, m., Yusuf, A., Dahlan, M., \& Tasmiah, T. (2021). PENERAPAN MODEL BERBASIS PROYEK DALAM MENINGKATKAN KETERAMPILAN MENULIS TEKS PROSEDUR SISWA KELAS VII H SMPN 21 KOTA MAKASSAR. Fon: Jurnal Pendidikan Bahasa dan Sastra Indonesia, 17(2), 272-280. doi:https://doi.org/10.25134/fon.v17i2.4744

\section{PENDAHULUAN}

Proses pembelajaran dan Pendidikan di sekolah menjadi pilar utama. Tercapai atau tidaknya tujuan pendidikan sangat ditentukan dari proses pembelajaran. Berbagai mata pelajaran diajarkan di sekolah, salah satunya adalah Bahasa Indonesia. Bahasa Indonesia merupakan salah satu identitas bangsa Indonesia, karena itu mata pelajaran Bahasa Indonesia memiliki posisi yang strategis dalam kurikulum sekolah, sehingga pembelajaran Bahasa Indonesia memiliki peranan penting pada saat kegiatan belajar mengajar di sekolah

Pembelajaran bahasa Indonesia memiliki peranan penting untuk meningkatkan keterampilan berbahasa siswa di sekolah. Oleh karena itu, pembelajaran bahasa Indonesia dapat diartikan sebagai serangkaian aktivitas yang dilakukan siswa untuk mencapai keterampilan berbahasa yang baik. Untuk mencapai keterampilan berbahasa yang baik,guru dituntut harus mampu mengembangkan kreativitas berpikir yang dapat meningkatkan keterampilan berbahasa siswa dalam pembelajaran bahasa Indonesia.

Berdasarkan silabus mata pelajaran bahasa Indonesia yang sesuai dengan kurikulum 2013, salah satu tema pembelajaran bahasa Indonesia pada kompetensi dasar (KD) 3.1 Memahami struktur kaida teks anekdot,eksposisi, laporan hasil observasi, prosedur kompleks, dan negosiasi baik lisan maupun tulisan dengan alokasi waktu 34 JP X 45 MENIT (8 minggu, 17 pertemuan).
Teks prosedur kompleks terlaksana dengan baik apabila guru membuat rencana pelaksanaan pembelajaran (RPP) sesuai dengan kurikulum 2013. Belajar mengenai teks prosedurkompleks sangatlah penting. Pada teks prosedur kompleks peserta didik dapat mengetahui langkah-langkah yang harus ditempuh pada saat akan melakukan sesuatu. Langkah-langkah tersebut dilakukan untuk mengikuti tahap dalam suatuproses, dan akan mengeksplorasi teks prosedur kompleks. Mengapa pembelajaran menulis teks prosedur kompleks menarik untuk diteliti karena dalam penelitian ini bertujuan untuk mengetahui kemampuan menulis teks prosedur kompleks dengan memprihatikan struktur,unsur kebahasaan dan unsur kebahasaan, dan isi secara lisan dan tulis.

Berdasarkan pada observasi yang dilakukan di awal, peneliti menemukan realita di lokasi bahwa keterampilan menulis teks prosedur siswa masih jauh dari KKM yang telah ditentukan. Peneliti yang berbincang langsung kepada guru mitra mata pelajaran bahasa Indonesia yang bersangkutan, mendapatkan informasi bahwa benar siswa belum mampu menulis teks prosedur sesuai dengan yang diharapkan dan yang menjadi target ketuntasa di sekolah tersebut. Kemampuan menulis teks prosedur siswa masih rendah, masih mengalami kesulitan untuk menyusun teks yang sesuai dengan isi, tema yang dipilih, menuangkan ide kedalam bentuk tulisan, menyusun paragraph yang runtut dan padu, memilih dan menggunakan kosa kata yang tepat, menyusun kalimat efektif dan menggunakan ejaan yang tepat. 
Program Studi Pendidikan Bahasa dan Sastra Indonesia FKIP Universitas Kuningan

Berangkat dari realita yang ada dilapangan tersebut, peneliti berinisiatif dan tertarik menjadikan bahan pengkajiannya. Kurangnya motivasi dan tidak percaya diri siswa dalam menyampaikan gagasannya melalui media tulis merupakan salah satu faktor ketidakberhasilan dalam menulis teks prosedur itu sendiri.

Penelitian yang membahas tentang menulis sebelumnya pernah dibahas oleh Alan Novendra Junaedi (2013) dengan Judul Penelitian "Keefektifan Pendidikan Proses pada Pembelajaran Menulis Teks Eksposisi Siswa Kelas X SMA Negeri 1 Cisaat Kabupaten Sukabumi Jawa Barat". Yang membahas mengenai kemampuan membedakan kemampuan menulis teks eksposisi antara kelompok yang mengikuti pembelajaran menggunakan pendekatan proses dengan kelompok yang mengikuti pembelajaran tanpa menggunakan pendekatan proses.

Model pembelajaran berbasis proyek (Project Based Learning) bisa menjadi salah satu alternatif selanjutnya yang dikembangkan untuk model pembelajaran menulis teks narasi. Model pembelajaran Model pembelajaran berbasis proyek (Project Based Learning) merupakan model pembelajaran inovatif yang melibatkan kerja proyek dimana peserta didik bekerja secara mandiri dalam mengkonstruksi pembelajarannya dan mengkulminasikannya dalam sebuah produk yang nyata. Model ini merupakan sebuah model pembelajaran yang menekankan aktivitas siswa dalam memecahkan berbagai permasalahan yang bersifat open-ended dan mengaplikasikan pengetahuan mereka dalam mengerjakan sebuah proyek untuk menghasilkan sebuah produk otentik tertentu.

Selanjutnya Buck Institute for Education (Sutirman, 2013), model pembelajaran Project Based Learning adalah suatu metode pengajaran sistematis yang melibatkan para siswa dalam mempelajari pengetahuan dan keterampilan melalui proses yang terstruktur, pengalaman nyata dan teliti yang dirancang untuk menghasilkan produk.

Dengan demikian, maka pembelajaran Model pembelajaran berbasis proyek (Project Based Learning) mampu membelajarkan diri dan kehidupan siswa baik di kelas atau di sekolah. Lingkungan belajarnya juga membina dan meningkatkan serta mengembangkan potensi diri siswa sekaligus memberikan pelatihan hidup senyata-nyatanya.

Berdasarkan uraian di atas penulis menerapkan salah satu model pembelajaran yaitu model pembelajaran berbasis proyek (Project Based Learning). Berangkat dari berbagai permasalahan tersebut peneliti mencoba menerapkan model tersebut terhadap keterampilan menulis teks prosedur dengan judul'Penerapan model pembelajaran berbasis proyek (Project Based Learning) dalam meningkatkan Kemampuan Menulis Teks prosedur pada Siswa Kelas VII SMP Negeri 21 Kota Makassar"

\section{METODE}

Penelitian ini digolongkan ke dalam penelitian tindakan kelas (PTK). Penelitian tindakan kelas ini dilakukan untuk menggambarkan dan mengamati proses belajar siswa melalui model Project Based Learning dalam peningkatan kemampuan menulis teks prosedur siswa kelas VII $\mathrm{H}$ SMPN 21 Kota Makassar. Mekanisme pelaksanaannya dengan dua siklus. Setiap siklus masing-masing dilaksanakan dengan tiga tahap, yaitu tahap (1) perencanaan, (2) tindakan dan pelaksanaan, (3) refleksi.

Lokasi penelitian ini dilakukan di SMPN 21 Kota Makassar, objek penelitian 
ini adalah guru mata pelajaran Bahasa Indonesia dan siswa kelas VII H SMPN 21 Kota Makassar. Subjek penelitian ini adalah siswa berjumlah 30 orang. Subjek ini dipilih berbagai pertimbangan: (1) Hasil pembelajaran kelas VIII dalam keterampilan menulis teks prosedu belum sesuai dengan kriteria ketuntasan minimal, (2) Pada umumnya siswa kurang memiliki minat dan motivasi dalam pembelajaran menulis teks prosedur karena belum menggunakan model pembelajaran berbasis proyek yang variatif karena keadaan tersebut, maka kemampuan menulis teks prosedur harus ditingkatkan dengan model pembelajaran berbasis proyek.

\section{Instrumen Tes}

Instrumen tes yang digunakan peneliti dalam penelitian ini adalah perintah siswa untuk mengamati dan menganalisa media dan alat proyek yang diberikan guru kemudian siswa disuruh untuk menulis teks prosedur sesuai degan apa yang dia lihat apa yang dialaminya, yang didalamnya tertera peristiwa, waktu, dan tempat kejadian. Tes tertulis ini dilakukan satu kali siklus I dan satu kali siklus II. Ada beberapa aspek yang akan dinilai oleh peneliti terhadap menulis teks prosedur yang dilakukan oleh siswa. Aspekaspek tersebut dikembangkan dari kompetensi dasar kelas VII SMP kurikulum 2013, yaitu menulis teks prosedur dengan menggunakan bahasa yang baik dan benar dengan target yang diharapkan peneliti dengan penerapan model pembelajaran berbasis proyek. Aspek-aspek tersebut yaitu keterkaitan antara tema dengan isi, kualitas isi, ejaan, tanda baca, pilihan kata, ketepatan tujuan, alat/bahan, Langkahlangkah dan manfaat serta kesimpulan dalam menulis teks prosedur.

\section{Instrumen Nontes}

Instrument nontes adalah instrument yang digunakan untuk menlengkapi data tes agar data yang diperoleh lebih valid. Instrument yang digunakan yaitu lembar observasi, pedoman wawancara, dan pedoman dokumentasi. Penelitian ini terdapat dua siklus. setiap siklus memiliki mempat struktur yakni merencanakan, tindakan, observasi, dan refleksi. Setelah dilakukan refleksi yang berupa analisis dan penilaian terhadap proses tindakan tersebut, akan timbul masalah yang harus diberikan perubahan maka dari itu memerlukan rencana lagi dan refleksi ulang.

\section{HASIL DAN PEMBAHASAN}

\section{A. Hasil}

Hasil penelitian yang dipaparkan pada bab ini yakni hasil dari tes dan nontes. Hasil tes meliputi siklus I dan siklus II. Hasil tes timdakan siklus I dan siklus II meliputi hasil keterampilan menulis teks prosedur dengan penerapan model berbasis proyek, Hasil tes siklus I adalah hasil tes keterampilan menulis berita untuk mendapatkan situasi awal keterampilan menulis teks prosedur dengan model berbasis proyek. Hasil tes siklus II adalah renovasi keterampilan menulis teks prosedur dengan model berbasis proyek. Hasil nontes diambil dari observasi, wawancara, dan dokumentasi.

\section{Tabel A. Daftar Nilai Siswa Pada Siklus I}

\begin{tabular}{|r|r|r|r|r|}
\hline $\begin{array}{r}\text { Peserta } \\
\text { Didik }\end{array}$ & 1 & 2 & Jumlah & Rata-Rata \\
\hline PS1 & 60 & 70 & 130 & 65 \\
\hline PS2 & 65 & 70 & 135 & 67,5 \\
\hline PS3 & 60 & 70 & 130 & 65 \\
\hline PS4 & 68 & 70 & 138 & 69 \\
\hline PS5 & 65 & 70 & 135 & 67,5 \\
\hline PS6 & 65 & 70 & 135 & 67,5 \\
\hline PS7 & 68 & 73 & 141 & 70,5 \\
\hline PS8 & 68 & 72 & 140 & 70 \\
\hline PS9 & 67 & 70 & 137 & 68,5 \\
\hline PS10 & 67 & 70 & 137 & 68,5 \\
\hline & & & & \\
\hline
\end{tabular}


Program Studi Pendidikan Bahasa dan Sastra Indonesia FKIP Universitas Kuningan

\begin{tabular}{|r|r|r|r|r|}
\hline PS11 & 60 & 70 & 130 & 65 \\
\hline PS12 & 60 & 70 & 130 & 65 \\
\hline PS13 & 65 & 70 & 135 & 67,5 \\
\hline PS14 & 66 & 72 & 138 & 69 \\
\hline PS15 & 67 & 72 & 139 & 69,5 \\
\hline PS16 & 66 & 70 & 136 & 68 \\
\hline PS17 & 65 & 70 & 135 & 67,5 \\
\hline PS18 & 60 & 72 & 132 & 66 \\
\hline PS19 & 65 & 72 & 137 & 68,5 \\
\hline PS20 & 67 & 73 & 140 & 70 \\
\hline PS21 & 65 & 71 & 136 & 68 \\
\hline PS22 & 65 & 70 & 135 & 67,5 \\
\hline PS23 & 65 & 70 & 135 & 67,5 \\
\hline PS24 & 65 & 70 & 135 & 67,5 \\
\hline PS 25 & 60 & 65 & 125 & 62,5 \\
\hline PS 26 & 65 & 70 & 135 & 67,5 \\
\hline PS 27 & 70 & 65 & 135 & 67,5 \\
\hline PS 28 & 65 & 65 & 130 & 65 \\
\hline PS 29 & 70 & 65 & 135 & 67,5 \\
\hline PS 30 & 70 & 70 & 140 & 70 \\
\hline Rata-Rata & 65,67 & 69,65 & 4.051 & 67.51 \\
\hline
\end{tabular}

Tabel b. Frekuensi dan Kategori Siklus I

\begin{tabular}{|r|r|r|r|r|}
\hline No & $\begin{array}{r}\text { Rentang } \\
\text { Nilai }\end{array}$ & Frekuensi & Persentase & Kategori \\
\hline 1 & $85-100$ & - & - & $\begin{array}{r}\text { Sangat } \\
\text { baik }\end{array}$ \\
\hline 2 & $70-84$ & 4 & $13,3 \%$ & Baik \\
\hline 3 & $60-69$ & 26 & $86,6 \%$ & Sedang \\
\hline 4 & $50-59$ & - & - & Kurang \\
\hline 5 & $0-49$ & - & & $\begin{array}{r}\text { Sangat } \\
\text { Kurang }\end{array}$ \\
\hline
\end{tabular}

\section{Tabel c. Hasil Nontes Siklus I}

\begin{tabular}{|r|r|r|r|}
\hline No & $\begin{array}{r}\text { Indikator yang } \\
\text { diamati }\end{array}$ & rekuensi & $\begin{array}{r}\text { Persentase } \\
(\%)\end{array}$ \\
\hline 1 & $\begin{array}{r}\text { Kesiapan siswa } \\
\text { dalam mengikuti } \\
\text { pelajaran }\end{array}$ & 20 & 83,33 \\
\hline 2 & $\begin{array}{r}\text { Siswa yang } \\
\text { mengajukan } \\
\text { solusi ketika } \\
\text { guru }\end{array}$ & 17 & 70,83 \\
& $\begin{array}{r}\text { memberikan } \\
\text { masalah untuk } \\
\text { memotivasi }\end{array}$ & & \\
\hline
\end{tabular}

\begin{tabular}{|c|c|c|c|}
\hline & $\begin{array}{r}\text { diawal } \\
\text { pembelajaran }\end{array}$ & & \\
\hline 3 & $\begin{array}{r}\text { Siswa yang } \\
\text { mengajukan } \\
\text { pertanyaan } \\
\text { terhadap masalah } \\
\text { yang diberikan }\end{array}$ & 15 & 62,5 \\
\hline 4 & $\begin{array}{r}\text { Siswa aktif } \\
\text { berdiskusi } \\
\text { dalam kelompok } \\
\text { untuk rencana } \\
\text { proyek }\end{array}$ & 10 & 41,16 \\
\hline 5 & $\begin{array}{r}\text { Siswa yang } \\
\text { menanggapi } \\
\text { solusi } \\
\text { permasalahan } \\
\text { yang diajukan } \\
\text { oleh siswa lain } \\
\text { dalam kelompok } \\
\end{array}$ & 13 & 54,17 \\
\hline 6 & $\begin{array}{r}\text { Siswa yang aktif } \\
\text { bekerja sama } \\
\text { dalam kelompok } \\
\text { untuk } \\
\text { menyelesaikan } \\
\text { proyek }\end{array}$ & 12 & 50,00 \\
\hline 7 & $\begin{array}{r}\text { Siswa yang } \\
\text { melakukan } \\
\text { kegiatan lain } \\
\text { ketika proses } \\
\text { pembelajaran } \\
\text { berlangsung. }\end{array}$ & 14 & 58,33 \\
\hline
\end{tabular}

Tabel a. Daftar Nilai Siswa pada Siklus II

\begin{tabular}{|r|r|r|r|r|r|}
\hline No & $\begin{array}{r}\text { Peserta } \\
\text { Didik }\end{array}$ & 1 & 2 & Jumlah & $\begin{array}{r}\text { Rata- } \\
\text { Rata }\end{array}$ \\
\hline 1 & PS1 & 75 & 85 & 160 & 80 \\
\hline 2 & PS2 & 76 & 80 & 156 & 78 \\
\hline 3 & PS3 & 75 & 80 & 155 & 77,5 \\
\hline 4 & PS4 & 80 & 82 & 162 & 81 \\
\hline 5 & PS5 & 75 & 90 & 165 & 82,5 \\
\hline 6 & PS6 & 78 & 85 & 163 & 81,5 \\
\hline 7 & PS7 & 77 & 80 & 157 & 78,5 \\
\hline 8 & PS8 & 78 & 85 & 163 & 81,5 \\
\hline 9 & PS9 & 80 & 85 & 165 & 82,5 \\
\hline 10 & PS10 & 80 & 85 & 165 & 82,5 \\
\hline 11 & PS11 & 78 & 85 & 163 & 81,5 \\
\hline 12 & PS12 & 75 & 80 & 155 & 77,5 \\
\hline 13 & PS13 & 80 & 85 & 165 & 82,5 \\
\hline 14 & PS14 & 80 & 85 & 165 & 82,5 \\
\hline 15 & PS15 & 75 & 80 & 155 & 77,5 \\
\hline 16 & PS16 & 77 & 85 & 162 & 81 \\
\hline 17 & PS17 & 77 & 85 & 162 & 81 \\
\hline 18 & PS18 & 77 & 80 & 157 & 78,5 \\
\hline 19 & PS19 & 85 & 90 & 175 & 87,5 \\
\hline 20 & PS20 & 78 & 85 & 163 & 81,5 \\
\hline
\end{tabular}


Program Studi Pendidikan Bahasa dan Sastra Indonesia FKIP Universitas Kuningan

\begin{tabular}{|l|r|r|r|r|r|}
\hline 21 & PS21 & 78 & 85 & 163 & 81,5 \\
\hline 22 & PS22 & 75 & 80 & 155 & 77,5 \\
\hline 23 & PS23 & 75 & 85 & 160 & 80 \\
\hline 24 & PS24 & 70 & 85 & 155 & 77,5 \\
\hline 25 & PS 25 & 80 & 80 & 160 & 80 \\
\hline 26 & PS 26 & 90 & 80 & 170 & 85 \\
\hline 27 & PS 27 & 75 & 85 & 160 & 80 \\
\hline 28 & PS 28 & 75 & 90 & 165 & 82,5 \\
\hline 29 & PS 29 & 80 & 80 & 160 & 80 \\
\hline 30 & PS 30 & 75 & 85 & 160 & 80 \\
\hline & & & & & \\
& Rata-Rata & 78,28 & 83,58 & 4,841 & 80,63 \\
& & & & & \\
\hline
\end{tabular}

Tabel b. Frekuensi dan Kategori Siklus II

\begin{tabular}{|r|r|r|r|r|}
\hline No & $\begin{array}{r}\text { Rentang } \\
\text { Nilai }\end{array}$ & Frekuensi & $\begin{array}{r}\text { Persen } \\
\text { tase }\end{array}$ & Kategori \\
\hline 1 & $85-100$ & 2 & $6,66 \%$ & $\begin{array}{r}\text { Sangat } \\
\text { Baik }\end{array}$ \\
\hline 2 & $70-84$ & 28 & $93,33 \%$ & Baik \\
\hline 3 & $60-69$ & - & - & Sedang \\
\hline 4 & $50-69$ & - & - & Kurang \\
\hline 5 & $0-49$ & - & - & $\begin{array}{r}\text { Sangat } \\
\text { Kurang }\end{array}$ \\
\hline
\end{tabular}

Tabel c. Hasil Nontes Siklus II

\begin{tabular}{|c|c|c|c|}
\hline No & $\begin{array}{r}\text { Indikator yang } \\
\text { diamati }\end{array}$ & Frekuensi & $\begin{array}{r}\text { Persentase } \\
(\%)\end{array}$ \\
\hline 1 & $\begin{array}{r}\text { kesiapan siswa } \\
\text { dalam } \\
\text { mengikuti } \\
\text { pelajaran } \\
\end{array}$ & 24 & 100 \\
\hline 2 & $\begin{array}{r}\text { Siswa yang } \\
\text { mengajukan } \\
\text { solusi ketika } \\
\text { guru } \\
\text { memberikan } \\
\text { masalah untuk } \\
\text { memotivasi } \\
\text { diawal } \\
\text { pembelajaran }\end{array}$ & 22 & $91,67 \%$ \\
\hline 3 & $\begin{array}{r}\text { Siswa yang } \\
\text { mengajukan } \\
\text { pertanyaan } \\
\text { terhadap } \\
\text { masalah yang } \\
\text { diberikan }\end{array}$ & 21 & $87,5 \%$ \\
\hline
\end{tabular}

\begin{tabular}{|c|c|c|c|}
\hline 4 & $\begin{array}{r}\text { Siswa yang } \\
\text { mengajukan } \\
\text { solusi dalam } \\
\text { kelompok } \\
\text { terhadap } \\
\text { masalah yang } \\
\text { diberikan } \\
\end{array}$ & 20 & $83,33 \%$ \\
\hline 5 & $\begin{array}{r}\text { Siswa yang } \\
\text { menanggapi } \\
\text { solusi } \\
\text { permasalahan } \\
\text { yang diajukan } \\
\text { oleh siswa lain } \\
\text { dalam } \\
\text { kelompok } \\
\end{array}$ & 19 & $79,16 \%$ \\
\hline 6 & $\begin{array}{r}\text { Siswa yang aktif } \\
\text { bekerja sama } \\
\text { dalam } \\
\text { kelompok untuk } \\
\text { menyelesaikan } \\
\text { masalah }\end{array}$ & 18 & $75,00 \%$ \\
\hline 7 & $\begin{array}{r}\text { Siswa yang tidak } \\
\text { melakukan } \\
\text { kegiatan lain } \\
\text { ketika proses } \\
\text { pembelajaran } \\
\text { berlangsung. }\end{array}$ & 18 & $75,00 \%$ \\
\hline
\end{tabular}

\section{B. Pembahasan}

Penelitian ini bertujuan untuk meningkatkan keterampilan menulis teks prosedur dengan menggunakan model pembelajaran berbasis proyek. Materi yang diajarkan pada penelitian ini adalah Peningkatan keterampilan menulis teks prosedur yang diperoleh pada penelitian ini berupa nilai hasil belajar. Dalam hal ini kelas diajar dengan model pembelajaran Berbasis proyek. Tahap ini peneliti memaparkan garis besar hasil penelitian mulai dari pratindakan hingga siklus II.

Pada tahap pratindakan, dalam hal ini peneliti memberikan untuk siswa. Dari hasil tersebut dapat diketahui bahwa siswa sudah pernah mendapat pengetahuan dan tugas menulis teks prosedur dari guru. Akan tetapi, hanya sebagian siswa yang senang ketika diberi tugas oleh guru untuk menulis teks berita. Terkadang siswa menulis karya satra lain seperti puisi atau novel. Hampir sebagian siswa kurang mengetahui tahapan menulis teks dengan 
baik. Hal ini disebabkan karena guru sering menggunakan metode presentasi dan diskusi.

Guru juga menggunakan buku paket ketika menyampaikan materi, sehingga kurang memaksimalkan metode dan media pembelajaran. Selanjutnya, siswa sering diberi tugas untuk dikerjakan di rumah. Hal ini menyebabkan siswa merasa bosan saat mengikuti kegiatan pembelajaran di kelas. Oleh karena itu, siswa tertarik untuk mengikuti pembelajaran membaca pemahaman menggunakan pendekatan kontekstual dan media pembelajaran yang baru.

Pada siklus I siswa cukup bersemangat untuk mengikuti pembelajaran menggunakan pendekatan kontekstual, dalam hal ini guru berinisiatif untuk membentuk membahas mengenai langkah-langkah menulis teks prosedur yang benar. Siswa lebih mudah mendapatkan ide dalam menulis teks prosedur. Selain menentukan gagasan, siswa juga mengingat tahapan menulis teks prosedur dengan benar.

Pada data siklus I siswa SMPN 21 kota Makassar dengan pemberian uji test membuat teks prosedur dan pemberian skor. Dengan total skor keseluruhan siswa 4.051 dengan dua kali uji test. Uji test pertama dengan nilai rata-rata 65,67 sedangkan nilai rata-rata uji test kedua 69,65 keseluruhan dari uji test pertama dan kedua yakni 67,51 dalam kategori cukup, sehingga dilakukan tahapan selanjutnya.

Pada data siklus II siswa SMPN 21 kota Makassar dengan pemberian uji test membuat teks prosedur dan pemberian skor. Dengan total skor keseluruhan siswa 4.841 dengan dua kali uji test. Uji test pertama dengan nilai rata-rata 78,28 , nilai rata-rata uji test kedua 83,58 . Total ratarata keseluruhan dari uji test pertama sampai letiga yakni 80,63 dalam kategori baik.
Berdasarkan hasil penelitian ini, penggunaan model berbasis proyek dengan melakukan perubahan pada perencanaan dan tindakan mendapatkan hasil perbedaan yang terdapat dalam siklus I dan siklus II yang signifikan.

\section{KESIMPULAN}

Berdasarkan data siklus I siswa SMPN 21 kota Makassar dengan pemberian uji test membuat teks prosedur dan pemberian skor. Dengan total skor keseluruhan siswa 4.051 dengan dua kali uji test. Uji test pertama dengan nilai ratarata 65,67 sedangkan nilai rata-rata uji test kedua 69,65 keseluruhan dari uji test pertama dan kedua yakni 67,51 dalam kategori cukup, sehingga dilakukan tahapan selanjutnya. Pada data siklus II siswa SMPN 21 kota Makassar dengan pemberian uji test membuat teks prosedur dan pemberian skor. Dengan total skor keseluruhan siswa 4.841 dengan dua kali uji test. Uji test pertama dengan nilai ratarata 78,28 , nilai rata-rata uji test kedua 83,58 . Total rata-rata keseluruhan dari uji test pertama sampai letiga yakni 80,63 dalam kategori baik. Aktivitas siswa dalam penerapan model berbasis proyek pada siklus 1 dikategorikan cukup aktif $66,67 \%$ mengalami peningkatan di siklus II yang dikategorikan aktif 76,67\%.

\section{DAFTAR PUSTAKA}

Al Aliyah, O. I. (2017). Pengembangan Media Video SlideBerbasis Audio Visual dalam Pembelajaran Menulis Teks Prosedur Siswa Kelas VII SMP Negeri 21 Surabaya Tahun Pelajaran 2016/2017. Bapala, 4(1).

Akhadiah, Sabarti.dkk .1997. Menulis. Jakarta: Depdikbud

Ariyatna, E. (2014). Pengaruh Model Pembelajaran Berbasis Masalah terhadap Kemampuan 
Program Studi Pendidikan Bahasa dan Sastra Indonesia FKIP Universitas Kuningan

Menulis Teks Prosedur Kompleks Siswa Kelas X SMK Negeri 3 Medan Tahun Pembelajaran

2014/2015 (Doctoral

dissertation, UNIMED). .1995.

Pembinaan Kemampuan
Menulis Bahasa Indonesia.
Jakarta: Erlangga

Chatarina, Y., Maridjo, A. H., \& Sabri, T. Peningkatan Keterampilan Menulis Karangan Narasi Menggunakan Metode Latihan Siswa Kelas V Sdn 01 Ketapang. Jurnal Pendidikan dan Pembelajaran Khatulistiwa, 3(2).

Devi, P. C., Hudiyono, Y., \& Mulawarman, W. G. (2018). Pengembangan Bahan Ajar Menulis Teks Prosedur Kompleks dengan Model Pembelajaran Discovery Learning Menggunakan Media Audio Visual (Video) di Kelas XI SMA Negeri 1 Samarinda. Diglosia: Jurnal Kajian Bahasa, Sastra, Dan Pengajarannya, 1(2), 101-114.

Junus, Andi Muhammad. 2011. Keterampilan Berbahasa Tulis. Makassar: Badan Penerbit Universitas Negeri Makassar

Junus, Andi Muhammad.2009.

Pembentukan Kalimat Bahasa Indonesia. Cet.Ke 1.Makassar: Badan Penerbit UNM

Jabrohim. 2003. Metodologi Penelitian Sastra.Yokyakarta: Hanindita Graha Widya

Keraf, G.2010. Argumentasi Dan Narasi. Jakarta: Gramedia

Lestari, S. (2009). Upaya meningkatkan keterampilan menulis siswa dengan pendekatan kontekstual (Doctoral dissertation, UNS (Sebelas Maret University)).

Lestari, D. W., Dian, H., \& Sudrajat, R. T. (2018). Pembelajaran Menulis Teks Prosedur dengan Menggunakan Metode CTL (Contextual Teaching and Learning) pada Siswa Kelas X MAN Cimahi. Parole (Jurnal Pendidikan Bahasa dan Sastra Indonesia), 1(5), 815-820.

Margono. 2007.

MetodelogiPenelitianPendi dikan. Jakarta: RinekaCipta. Sudaryono.

Munirah. 2015. Pengembangan

Keterampilan Menulis

Paragraf.Ed.Cet

1.Yogjakarta: Deepublish

Mursalin, R. F., \& Cahyani, I. (2018, November).

PENGGUNAAN MODEL PEMBELAJARAN

BERBASIS PROYEK

TERHADAP

KEMAMPUAN MENULIS

TEKS EKSPOSISI.

In Seminar Internasional

Riksa Bahasa (pp. 11791190).

Parera, J Daniel. 1993 Sintaksis. Jakarta: PT Gramedia Pustaka Umum

Pratiwi, E., Sunarti, I., \& Fuad, M. (2019). Pengembangan LKPD Menulis Cerita Fantasi Dengan Project Based Learning Untuk Siswa SMP. J-SIMBOL (Bahasa dan Sastra Indonesia), 7(2).

Sandy, F., \& Kosasih, E. (2019). PENERAPAN MODEL PEMBELAJARAN BERBASIS PROYEK BERBANTUAN MEDIA KOMIK DIGITAL DALAM PEMBELAJARAN MENULIS TEKS PUISI TERHADAP SISWA KELAS VIII SMP NEGERI 2 
Program Studi Pendidikan Bahasa dan Sastra Indonesia

FKIP Universitas Kuningan

\begin{tabular}{lc|ccc} 
SUBANG. $\quad$ In Seminar. & $\ldots \ldots \ldots \ldots \ldots$......1993. Metode Penelitian \\
Internasional Riksa Bahasa. & Sastra.Bandung: Angkasa &
\end{tabular}

Suparno dan Muhammad Yunus. 2004Sutikno, Sobry.2014.Metode Dan Model-

Keterampilan Dasar

Menulis.Jakarta: Universitas

Terbuka

Sundyana.2017.

Peningkatan

Kemampuan Menulis Melalui

Model Project Based Learning

Pada Peserta Didik Kelas VII

SMP NEGERI 1 Tumi Jajar.

Tesis. Bandar Lampung:

Universitas Lampung

Suliani, Ni NyomanWetty. 2011. StrategiPembelajaranBahasada

$n \quad$ Sastra Indonesia. Materi Ajar: Universitas Lampung.

Suprananto, Kusaeri. 2012.

PengukurandanPenilaianPendi

dikan. Yogyakarta: GrahaIlmu.

Slamet. 2008. Dasar-Dasar Keterampilan

Berbahasa Indonesia.Surakarta.

UNS Press

Semi, M.Atar.1993. Dasar-Dasar

Keterampilan Menulis.Bandung:

Angkasa
Model Pembelajaran.Lombok: Holistica

Tarigan, Hendry Guntur.2008.Membaca

Sebagai Suatu Keterampilan

Berbahasa.Bandung: Angkasa

Tarigan, Guntur Henry. 1993.

Strategi

PengajarandanPembelajaran

Bahasa.Bandung: Angkasa.

Trianto. 2009. Mendesain Model Pembelajaran Inovatif-

Progresif.Jakarta:Kencana

Prenada Media Group.

Yusuf, A. B. (2017). KEEFEKTIFAN MODEL PEMBELAJARAN BERBASIS PROYEK TERHADAP KEMAMPUAN MENULIS SISWA KELAS VIII SMP NEGERI 33 MAKASSAR. JURNAL KONFIKS, 4(1), 83-94. 